\title{
Nagari Madani Movement: A Social Policy-Based Islamic Values In Agam Regency
}

\author{
1 ${ }^{\text {st }}$ ZikriAlhadi \\ Universitas Negeri Padang, Padang, \\ Indonesia \\ $2^{\text {nd Isnarmi Moeis* }}$ \\ Universitas Negeri Padang, Padang, \\ Indonesia \\ Isnarmi213@fis.unp.ac.id
}

\author{
$3^{\text {rd }}$ Eriyanti \\ Universitas Negeri Padang,Padang, \\ Indonesia \\ $4^{\text {th }}$ RahmadaniYusran \\ Universitas Negeri Padang,Padang, \\ Indonesia \\ $5^{\text {th }}$ Murniyetti \\ Universitas Negeri Padang, Padang, \\ Indonesia
}

\begin{abstract}
The 'Back to Nagari' policy initiated by the West Sumatra Provincial Government, followed by several districts / cities, essentially the reinforcement of the existence of the Nagari as the single lowest government institution in Minangkabau. Not only related to the administration of the government, back to Nagari focuses on the arrangement of local institutions. In Agam Regency, the local government has initiated the Movement of Nagari Madani as a form of "Back to Nagari" which focuses on optimizing the economic and social conditions.
\end{abstract}

This policy tends to be top down from government initiatives. The main basis of NagariMadani is values that have been developed by Prophet Muhammad in running the government and organizing the

\section{INTRODUCTION}

Social policy is a form of policy where the social policy is a government regulation made for respond the public issues I.e. overcoming social problems or provide public needs. According to [1] social policy refers to what governments do when they attempt to community in the Medina City. These values focus on: the principle of equality, deliberation and consensus, the value of ukhuwah, fostering the love of the homeland and the recognition of human rights. So that the implementation of the policy of Nagari Madani aims to create a society that has freedom, justice, participation and egalitarian. And with the achievement of these goals can be a solution to the social problems faced by the community. To this end, this article describes the policy of local government to achieve the level of Nagari Madani as aspired in the Vision of RPJPD 2006-2025 and its relevance to solving social problems in Agam Regency.

Keywords-Social Policy, Civil Society, Nagari

improve the quality of people's lives by providing a range of income support, community services and support programs".

Madani is the virtuous or noble society, civilized society, "civil society". The civil society built by the prophet. Robert N. Bellah, a sociology of leading religion, called as the 
very modern even too modern era at the time so after the prophet himself died it did not last long. Middle East and mankind at that time were not ready with the social infrastructure needed to support a modern social order as initiated by the Prophet[2].

Starting from the view of the vibrant life of God with the consequences of acts of kindness to fellow human beings (Holy Quran : Fushshilat: 33 ), civil society stands on the justice includes steadfastness in holding the law. Enforcing the law is the mandate of God Almighty, which is ordered to be carried out to those who are entitled (Holy Quran An-Nisa: 58). The Prophet has given us examples. He very faithfully carried out God's command. Moreover, the Qur'an also asserts that the sacred duty of all the Prophets is to uphold justice among humans [3]

According to M. Soim the character of civil society is as follows:

1. The fulfillment of the basic needs of individuals, families and groups in society.

2. The development of human capital and social capital which is conducive to the ability to carry out life tasks and the establishment of trust and social relations between groups.

3. Absence of discrimination in various fields of development; in other words, open access to various social services.

4. There is the ability and opportunity rights for communities and non-governmental organizations to be involved in various forums where issues of mutual interest and public policy can be developed.

5. The existence of cohesiveness between groups in society and the growing mutual respect for differences between cultures and beliefs.

6. The implementation of a government system that allows economic, legal and social institutions to run productively and socially.

7. There are guarantees, certainty and trust between social networks that allow the establishment of relationships and communication between them regularly, openly and reliably.

As a form of social policy to create civil society, the 'back to nagari' movement initiated by the West Sumatra Provincial Government basically reinforces the existence of the nagari as the lowest government institution in Minangkabau. Not only related to the administration of the government, returning to the nagari focuses on the arrangement of local institutions. There are four basic things that become the prerequisites for structuring local institutions, namely: culture as a guideline for the existence of institutions, the connection between culture and government, interpretations that view culture as a political sub-system of government, and placing a politically subordinated system in a strong cultural system both in the order of ideas and in implementation [4].

In order to realize the policy of back to Nagari, the Agam Regency Government initiated the NagariMadani Movement which was legalized in Agam Regent Regulation No. 74 of 2016 about Guidelines for the implementation of the NagariMadani movement. In Chapter I of the General Provisions, it was stated that "NagariMadani is a religious / Islamic nagari, which has a high civilization and progress which is based on the values, norms, laws and morals of Adat Basandi Syarak, Syarak Basandi Kitabullah, Syarak Mangato Adat Mamakai (a Minangkabau philosophy means Minangkabau custom is based on the Islamic values while the regulations in Islam are explained on Alquran). A society based on Islamic brotherhood, respecting differences, being democratic and open (inclusive), mutual cooperation, and kinship." This statement is a show that the administration of government and the arrangement of society in Minangkabau will not be separated from the Islamic values.

Eventhough, re-applying cultural values and Islamic law in the government and society is not an easy matter. After decades of being 'alienated' from the nagari government as a customary government and 'forced' to 
run a modern government system with a format of central government under the New Order regime, the implementation of the current nagari government is faced with various obstacles, start from the changing government performance until the pace of political change government that is not in line with the pace of social change [5].

As an unavoidable part of the implementation of the Nagarimadani Movement with its core 'baliakbasurau' back to mushala (interview with the Deputy Regent of Agam, Trianda Farhan Satria on March 23, 2017), the influence of modern culture needs to be taken into account as a factor that might hamper the success of this policy. As stated[6], surau in the present is increasingly marginalized due to the weakening of the sociocultural basis of the Minangkabau people themselves. Various sociocultural, religious and political changes that occurred in the period of "abolition of the nagari institution" in many ways harmed the existence of the surau.

At the level of implementation, Agam Regency Government is obliged to consider the pilot project of this policy before implementing it comprehensively. With an area divided into 82 nagari that stretches from the lowlands to the plateau and diverse social demographic conditions, it is easy to immediately apply this policy without a pilot project. The actual conditions were also realized by the district government, as stated by the Deputy Regent of Agam in an interview with the research team. The initial steps taken by the regency government were limited to focus group discussions, public discussions, and socialization in four locations at LadangLaweh, Kamang, Baso, and Canduang.

In general, the socialization in these areas indicated not represent social characteristics, economy, and demographic communities Agam. Based on the facts above, as well as considering the nature of this policy that tends top down, it is important to do research in order to find the design of the implementation of the nagariMadani movement that is in accordance with the needs and characteristics of the heterogeneous Agam Regency community, as well as in order to ensure the realization of the values of public welfare contained in this movement. Based on the fact, this study entitled "Study of the Implementation of the NagariMadani Movement in Agam Regency."

\section{METHOD}

The research approach used in this study is a qualitative research approach. In this study, qualitative methods are used to gain a broad understanding and the implementation of the Study of NagariMadani Movement in Agam by analyzing various factors relating to the factual conditions to be observed and studied holistically. So that the models will be developed to be used as best practice in social policy.

\section{RESULTS AND DISCUSSION}

The Birth of the NagariMadani Policy in Agam Regency was motivated by several crucial problems in Nagari. First, the behavior, actions and religious life of most people are still contrary to religion values and customary norms. Second, the grandeur of the physical building of worship facilities is not accompanied by the spiritual development of the community. Based on the two crucial issues, the policy that focuses on strengthening the application of the Islam values and the Minangkabau norms in daily life is born.

The concept of the Policy on NagariMadani is outlined in the vision of Agam Regency's Regional Long-Term Development Plan (RPJPD) 2006-2025. The RPJPD Vision is "Creating an Agam Regency that is Independent, Achieving and Madani". The word "Madani" here is intended to build the civilization of society at Nagari in Agam Regency so that it is in accordance with the demands of Islamic values based on Al-Quran and Al Hadists and Minangkabau norms which are based on "Adat Basandi Syarak, Syarak Basandi Kitabullah"

The main basis of Nagari Madani is the 
values that have been developed by the Prophet Muhammad SAW in running the government and organizing the community in Medina. These values focus on: the principle of equality, deliberation and consensus, ukhuwah value, fostering a sense of love for the homeland and recognition of human rights. So that the implementation of the NagariMadani policy aims to create a society that has the perspective of freedom, justice, participation and egalitarianism.

There are several concepts that will be implemented in the NagariMadani policy in Agam Regency, are:

1. The values which have been developed by the Prophet Muhammad in running the government and organizing the community in Medina.

2. The basic values of community life are based on: the principle of equality, deliberation and consensus, the value of ukhwah, fostering a sense of love for the homeland and recognition of the human rights of every human being.

3. The application of AgamMadani will be a society that has freedom, justice, participation and egalitarian perspectives.

This concept has been stated in the Vision of the Agam Regency's RPJPD 2006-2025 which Make an Independent, Achieving and Civilized of Agam Regency. This vision is how to build civilization at Nagari in Agam Regency. The explanation of the Agam Regency RPJPD vision is as follows:

\section{RPJPD 2006-2025 Vision}

Make an Independent, Achieving and Civilized of Agam Regency

\section{RPJMD 2010-2015 visions}

Make a religious, fair, Independent and natural of Agam Regency in order to strengthen the base to achieve an independent, achieving and Madani of agam

\section{RPJM 2016-2021 Vision}

Make a fair, Innovative, prosperous, and religious to be an independent, achieving, and madani of Agam Regency
In addition, the mission of the RPJPD Kab. Agam (2006 - 2025) are:

1. Improving Religious Life and Customary Norms Based on the Adatbasandisyarak, syarakbasandikitabullah.

2. Make a good, cleanand professional governance;

3. Improving the quality of human resources who are intelligent, healthy believers and character;

4. Improve regional economic competitiveness through quality, sustainable and equitable economic growth;

5. Improving the welfare of the community through the optimization of local resources based on creative and innovative community empowerment;

6. Developing a sustainable, environmentally sound, spatial, disaster mitigation and make Agam as the leading tourism destinations;

7. Increase the quantity and quality of physical, economic and social infrastructure.

Based on the seven missions above, the aim is towards the concept of NagariMadani with the objectives is strengthening the application of Islamic values in people's lives. Meanwhile the strategy are:

1. Optimize the function of the mosque,

2. Improve religious education in both formal and non-formal schools,

3. Encouraging the role of religious institutions,

4. Increase community social skills.

In the Nagari Madani Concept, several main objectives were formulated into:

1. The religious / Islamic nagari community, a high civilized and advanced society based on values, norms, law and morals of "Adat Basandi Syarak, Syarak Basandi Kitabullah, SyarakMangatoadatmamakai"

2. People who have a ukhuwwahislamiyyah education, respect differences, be democratic and inclusive, mutual cooperation and kinship.

3. Communities that all components 
cooperate in goodness, cooperate in the welfare of society and strengthen the faith and obedience to Allah SWT.

4. Communities who cooperate to protect the villages and communities from all threats, revive productive culture and educate the lives of nagari's young generation.

Social policy is one part of public policy. In the perspective of social policy, a social policy is a government decree to respond public issues to overcoming social problems or fulfilment the public needs [7]. Generally, scholars have the same view that social policy is also related to the government's efforts to improve the social welfare of its people ([8];). In fact, that social policy can be viewed as administrative centrality related to public values[9]. In this case, the policy of the Nagari Madani Movement (Gerakan Nagari Maadani -GNM) is a social policy initiated by the Regional Government of Agam as an effort to overcome the social problems, and develop the social values of society .

GNM is a policy where the process has been going on for a long time. The idea of GNM was previously rolled out by the previous regional head, Aristo Munandar. In the reign of Aristo Munandar, the Nagarimadani was more popularly referred to as the package of Islamic economic movements based on the nagari. Aristo Munandar's ideas re-developed in a different context at this time under the regent of IndraCharti and Deputy Regent Trinda Farhan Satria. At this time, the idea of the GNM was the political commodity of winning the regional head election which was then used as one of the vision and mission of the agam's local government. So, thus GNM is a political process that has been planned in such a way by the local government of Agam[8], [10].

In general, the Agam Regency government realizes that the current influence of technological progress and information has taken place, leading to changes in the lives of socio-religious communities in the region. In certain contexts, changes occur in the form of a mindset, acting and behaving society. As a result, shifts and changes in behavior that are not in accordance with religious values and customary norms adopted by the Agam community. Not only that, the Minangtraditional values based on the Qur'an and Sunnah are no longer used as habits in everyday life. Customary values, known as the philosophy of Adat Basandi Syarak, Syarak Basandi Kitabullah which are the main guidelines and references in regulating and directing people's lives indirectly begin to be abandoned. For example, impolate young generation, dress immodestly as opposed to the customary conditions. This problem is what underlies the GNM policy trying to improve the practice of religious and traditional values in Agam Regency.

As part of social policy, GNM has longterm goals and broad policy objectives. In the perspective of the Regional Government of Agam, the GNM policy covers the demographic, sociocultural aspects of the Agam region. the natural and socio-cultural conditions of the community in their area are very possible to formulate the GNM policy. In general, the area of Agam Regency is 2,232.30 $\mathrm{km}^{2}$ or $(5,29 \%)$ of the total area of West Sumatra Province which has an area of $42,229.04 \mathrm{~km}^{2}$. Of the total area, the growth of the population in Agam Regency is spread in 82 villages with 467 jorong (smallest village) in 16 sub-districts. Based on the 2015 population census, the population in Agam Regency is 476.90 people. This amount is the largest population in the West Sumatra Province, which is $5,196,300$ people. The wide scope of this GNM area also indicates that there is a strong desire from the Regional Government of Agam to unite the people in various civil program activities.

In realize the achievements of GNM, Article 4 Regent regulation No. 74 of 2016 above, also stipulates that the target of implementing GNM is the nagari government and the nagari community. The establishment of the Nagari government and the Nagari community as the GNM target is very basic. First, the Nagari government is the lowest government of the district government. Thus, 
through the various nagari government programs, coordination, communication and socialization can facilitate the implementation of GNM.

Second, at this time the nagari government already has its own resources in the administration of the nagari government. The existence of financial support from the central government in the form of village funds and the Agam Regency Budget, it is possible to optimize the achievements of GNM. Third, the village government also has the potential of a source and the other coming from overseas. Here are some reasons for implementing the nagarimadani with the hope of materializing Agammadani. In the perspective of the regional head, Agam Regency has a wide area with various forms of socio-cultural in each sub-district and its nagari. Achieving the civil society, it starts from the smallest community unit, the Nagari. so that if 82 nagari in Agam regency move towards the nigari madani, then the Agam regency will head towards Agammadani. In addition, the nagari now also has its own resources that come from the government. Even in certain cases the nagari also receives funds from overseas. This is the basis for the implementation of the nagari concept in the nagari.

Furthermore, in an effort to support the realization of the GNM, the regional government of Agam has integrated it into several other major policies. For example, Regent Regulations (Perbup) Agam No. 11 of 2015 concerning 2016 Agam Regency Regional Development Work Plan (RKPD); Agam Regency Regulation (Perda) No. 6 of 2016 concerning the 2016-202 Regional Medium Term Development Plan (RPJMD). Some of these regulations serve as guidelines for the implementation of GNM in AgamRegency which was followed later in the form of Nagari Regulations (Pernag) in various nagari governments [1].

Even so, the important issue that became the discussion of this study was, the extent of the program has had an impact on the nagari government and the community in realizing
GNM in Agam Regency. What are the programs that have been implemented in realizing GNM? Before explaining further about some of these issues, the GNM policy concept is discussed first.

\section{Policy Concept of Nagari Madani (GNM) in Agam Regency}

In Regent Regulation Agam Regency No. 74 Year 2016 on Guidelines for the Implementation of the Nagari Madani Movement stated that the main concepts villages civil in GNM is Nagari that religious / Islamic, which height civilization and forward based on the values, norms, laws and moral of Adat Basandi Syarak, Syarak Basandi Kitabullah, Syarak Mangato Adat Mamakai. A society based ukhuwwahIslamiyyah, respect differences, being a democratic and inclusive, mutual assistance and kinship. Sight from the concept of NagariMadani, the term madani is more inclined to the concept that follows the principle of life in the form of values developed by the Prophet Muhammadin governing and managing the society life that is used which is used as a basic value of social life based on the principles of justice, deliberation and consensus, the value of ukhuwwah, fostering a sense of love for the homeland and recognition of the human rights of every human being. This is the main concept of GNM policy in AgamRegency.

Furthermore, the concept of Nagai Madani above is emphasized in Article 2 of the Regent Regulations of Agam Regency No. 742016 which states that the concept of GNM is a will attempt to realize the understanding and practice of values to Islamization and traditional values Adat Basandi Syarak, Syarak Basandi Kitabullah (ABS-SBK) in order to realize the character of civil society. To realize the GNM, it is done through several efforts, 1) Optimizing Informal Education, especially the Qur'an (read, understand, practice, memorize); 2) Increasing the Role of Mosques/Surau as centers of social life; 3) Implementation of protection of villages and nagari communities; 4) Increased sense of social concern ukhuwah Islamiyah, kinship and mutual cooperation; 5) Costum 
application, cultural arts and sports in accordance with the customary philosophy of Adat basandi syarak, syarak basanadi kitabullah (ABS SBK); 6) Increasing the participation of institutions and community organizations; and 7) Increasing individual and social piety. This is the main goal of the achievement of GNM in Agam Regency. All these have been applied as community participation to support the local government policy [11].

Based on the GNM concept above, there are two fundamental focuses in GNM policy. Improving the lives of religious and customary norm based on principles of Adat Basandi Syarak, Syarak Basandi Kitabullah(ABS$S B K)$. First, improving religious life aims to strengthen the application of Islamic values in social lives, which can be realized by implementing the functions of mosques, improving religious education in both formal and non-formal schools, encouraging the role of religious institutions and improving social welfare. Second, in the field of custom and culture is an effort to preserve and revive traditional and cultural values that have become the philosophy of the Agam community, realized by strengthening the functions of traditional institutions in Nagari, preserving traditional arts as regional cultural wealth and tourist attraction. These two angels (ABS-SBK) in GNM policy were carried out simultaneously. It means that GNM also the reality of civil society movement [12], [13].

In connection with that, the birth of the NagariMadani'sconcept in AgamRegency is also closely related to the conditions of nature and its people. In this case, the Regional Religion has the characteristics of its civilized and religious community. Although, other regions in West Sumatra also have the same characteristics, but in Agam religious schools, such as madrasah Aliyah, boarding school and LPTQ schools are growing and developing very rapidly compared to other areas in West Sumatra. So this concept of NagariMadani then made as the vision and mission of the Agam Regency government.
Theimplementation of the Nagari Madani Movement in Agam Regency

The GNM policy has been implemented in various Nagari in Agam Regency. Almost all components of government and society welcome the euphoria of GNM. Several government institutions such as the Regional Moeslim Scholar Council (Majelis Ulama Indonesia-MUI), the Nagari Deliberation Agency (Badan Musyawarah-BAMUS), the Nagari Community Institution (Lembaga Kemasyarakatan Nagari-LKN), Kerapatan Adat Nadari (KAN) were actively involved in both the socialization and implementation of GNM in the nagari.

Based on the research findings, there are several GNM programs that have been implemented in the Nagari:

1. Optimization of Informal Education, especially the Qur'an (read, understand, practice, memorize)

2. Increasing the Role of Mosques / Surau as centers of social life

3. Implementation of protection of villages and nagari communities

4. Increased sense of social concern ukhuwah Islamiyah, kinship and mutual cooperation

5. Adat application, cultural arts and sports that are in accordance with the traditional philosophy of basandi syarak, syarak basanadi kitabullah (ABS SBK)

6. Increased participation of community institutions and organizations

7. Increased individual and social piety. This is the main goal of the achievement of GNM in Agam Regency.

Generally, the findings reveal that eachhead of Nagariand the community organization have carried out activities aimed at increasing the practice of the Qur'an values and traditional values that reflect ABS-SBK. For example, in various mosques have begun congregation Salatand the numbers are increasing, the "magrib mengaji"; recite the Qur'an after Salat Magrib, and the 
increasingly intense wirid (islam passage of Qur'an) recitation is being carried out by the women in the Nagari. However, such of religious activities have not been evenly implemented in every Nagari in Agam Regency. This is due to the availability of resources in each Nagari.

Another example of GNM implementation can be found in the increased understanding and practice of traditional values. For example, in nagari of KamangMagek, an initiative has emerged to make improvements in the customary area. This is done because so far many people do not know and understand the custom. For this reason, through the nagari deliberation initiated by the nagari government cooperate with the community, they tried to re-write the customary rules that had been written but had binding power in the community. The aim is to make the community can read and learn the custom, so that the community development will be accelerated [14].

However, activities that lead to these traditional values also have not developed significantly. Based on the findings the application of traditional values has not been supported by the emergence of indigenous learning centers in the Nagari. Unlike an increase in understanding and practice of religious values, learning the value of religion can be done regularly in the mosque.

However, indigenous learning has not been fully integrated with GNM. In factthere is still friction about the role and function of LKAM, KAN in carrying out various customary activities in the Nagari.

\section{CONCLUSIONS}

The GNM policy has now been implemented in various villages in Agam Regency. Almost all components of government and society welcomed the GNM euphoria. Some government institutions such as the Regional Ulama Council (MUI), the Musayawarah Nagari institution (BAMUS), the Nagari Community Institution (LKN), Kerapatan Adat Nadari (KAN) are involved in accordance with their respective contributions, both in the socialization and implementation of GNM in the nagari

The achievement of the GNM policy implementation in the program to improve understanding of Islamic values is very impressive. However, this achievement has not been followed by an increase in understanding and standardization of traditional values. This, seen from the lack of significant programs carried out leading to these traditional values. The process of planning and implementing GNM is entirely an initiative of the Regional Government of Agam and does not necessarily involve community participation. In general, the implementation of the GNM policy was made uniform and ignored differences in the characteristics of the community in each village.

\section{REFERENCES}

[1] H. Bochel and G. Daly. (2014). Social policy, third edition.Soc. policy, Third Ed., pp. 1-634.

[2] R. Bellah and P. Hammond.(2013). Varieties in Civil religion. Eugene, OR 97401: Wipf and Stock Publishers.

[3] M.Soim. (2015). Miniatur Masyarakat Madani (Perspektif Pengembangan Masyarakat Islam).Risalah, vol. 26, no. 1, pp. 23-32.

[4] N. Efendi. (2006). Pemerintahan Nagari Dalam Pemerintahan Adat in Pemerintahan Nagari dan Tanah Ulayat, A. Miko, Ed. Padang.

[5] D. Listiyawati, Sarmiati, and Asmawi. (2019). Komunikasi Perangkat Nagari dan Partisipasi masyarakat dalam Pengelolaan Dana Desa.JISPO, vol. 1.

[6] A. Azra. (2017).Surau Pendidikan Islam Tradisional dalam Transisi dan Modernisaso. Jakarta: Grameida Digital Nusantra.

[7] T. A. Wilson. (2012). Supporting social enterprises to support vulnerable consumers: The example of community development finance institutions and 
financial exclusion. J. Consum. Policy, 35(2), pp. 197-213.

[8] P. Spicker. (2014).Social Policy: Theory and Parctice. Chicago, IL: Policy Press.

[9] C. Casey. (2015). Public Values in Governance Networks: Management Approaches and Social Policy Tools in Local Community and Economic Development.Am. Rev. Public Adm., 45(1), pp. 106-127.

[10] S. B. M. Marume. (2016). Public Policy and Factors Influencing Public Policy," Int. J. Eng. Sci. Invent., 5(6), pp. 6-14.

[11] N. Barclay and L. Klotz. (2019). Role of community participation for green stormwater infrastructure development.
J. Environ. Manage., 251(4), p. 109620.

[12] M. I. Dachcolfany.(2012). Konsep Masyarakat Madani Dalam Islam. Akad. J. Pemikir. Islam, 17(1).

[13] A. F. Bakti. (2005). Islam and Modernity: Nurcholish Madjid's Inter pretation of Civil Society, Pluralism, Secularization, and Democracy.AJSS K. Brill NV, Leiden, vol. 33, no. 3, pp. 486506.

[14] J. Maraga, J. Kibwage, and B. Oindo. (2010). Factors determining community participation in afforestation projects in River Nyando basin, Kenya.African J. Environ. Sci. Technol., vol. 4, no. 12, pp. 853-859. 